\title{
Production and Characterization of Bio-Chars and Bio-Oils Formed by Pyrolysis of Persian Hogweed (Heracleum persicum Desf.) in A Fixed-Bed Reactor
}

\author{
Tevfik Aysu*
}

Yuzuncu Yil University, Department of Chemistry, 65080, Van, Turkey

\begin{abstract}
Pyrolysis of Persian Hogweed (Heracleum persicum Desf.) stalks were performed in a fixed-bed tubular reactor with $\left(\mathrm{K}_{2} \mathrm{CO}_{3}, \mathrm{ZnCl}_{2}\right)$ and without catalyst at three different temperatures $\left(400,500\right.$ and $\left.600{ }^{\circ} \mathrm{C}\right)$ with a constant heating rate of $50{ }^{\circ} \mathrm{C} / \mathrm{min}$. and with a constant sweeping gas $\left(\mathrm{N}_{2}\right)$ flow rate of $100 \mathrm{~cm}^{3} / \mathrm{min}$. The amounts of bio-char, biooil and gas produced were calculated and the compositions of the obtained bio-oils were characterized by GC-MS. The effects of pyrolysis parameters such as temperature and catalyst on the product yields were investigated. According to the results, both temperature and catalyst had significant effects on the conversion of Heracleum persicum Desf. into bio-chars, bio-oils and gaseous products. The highest bio-oil yield of $41.42 \%$ by weight including aqeous phase was achieved with $10 \%$ potassium carbonate catalyst at $500{ }^{\circ} \mathrm{C}$. 71 different compounds were identified by GC-MS in the biooils obtained at $500{ }^{\circ} \mathrm{C}$.
\end{abstract}

Keywords: Energy, Biomass, Pyrolysis, Bio-oil, Persian Hogweed, Heracleum persicum Desf.

\section{INTRODUCTION}

The demand for energy is increasing at an exponential rate due to the exponential growth of world population. This, combined with the widespread depletion of fossil fuels and gradually emerging consciousness about environmental degradation, suggests that the energy supply in the future has to come from renewable sources of energy. Statistics show that total renewable energy now accounts for nearly $18 \%$ of global primary energy supply, but out of this traditional biomass only about $30 \%$ account for over $55 \%$ by large hydro. Solar, wind, modern biomass, geothermal, small hydro (below $10 \mathrm{MW}$ ), and ocean energy all together account for only $12 \%$ of total renewable energy. The new and renewable account for only $2 \%$ of world primary energy supplies. Biomass contributes to about $12 \%$ of today's world primary energy supply, while in many developing countries its contribution ranges from $40 \%$ to $50 \%$ [1]. Renewable energy consumption was $8 \%$ of the total US energy consumption in 1997. Hydropower and biomass continued to dominate the renewable energy market, most of the year-to year drop was due to a decrease in biomass energy consumption due to a warmer than expected heating season [2].

The use of biomass as a substitute for fossil fuels, rather than solely for carbon sequestration, will enable biomass to play much wider roles in coping with greenhouse warming. With an increasing proportion of

*Address correspondence to this author at the Yuzuncu Yil University, Department of Chemistry, 65080, Van, Turkey; Tel: 9043222517 02; Fax: 90 43222513 69; E-mail: tevfikaysu@hotmail.com the world's population residing in developing countries, fossil fuels are decreasing and the countries have to import them. It is essential that greater effort should be put into producing and using biomass efficiently as a widely available and flexible fuel source [3]. Annually, photosynthesis stores 5-8 times more energy in biomass than man currently consumes from all sources [4]. Yearly 150 GT (4431 EJ) energy is produced by photosynthesis. This energy is approximately 10 times greater than the world primary energy consumption. Biomass provides a potential source of added value chemicals, such as reducing sugars, furfural, ethanol and other products, by using biochemical or chemical and thermochemical processes [5].

Production of energy from biomass by conversion could be achieved by using two main processes which are thermochemical and biochemical. Biochemical processes are used to produce mainly bio-ethanol, biogas and hydrogen [6]. Thermochemical processes include gasification, combustion, and pyrolysis [7]. In the thermochemical processes, pyrolysis has received much more attention than other processes in recent years. The yields of pyrolysis products depend on mainly the composition of raw material, pyrolysis process type and pyrolysis parameters such as temperature, heating rate, catalyst, residence time and sweeping gas flow rate [8].

One of the methods used in pyrolysis to produce hydrocarbon fuels is catalytic pyrolysis in carboncarbon bonds in bio-oil compounds are ruptured in the presence of some shape selective catalysts. Decarboxylation, dehydration, and decarbonylation of compounds are the cracking reactions which produce 
aromatic hydrocarbons, carbon dioxide and water. Using catalyst in pyrolysis processes produces a better quality of bio-oil at atmospheric pressure without using hydrogen gas that makes it cheaper than hydrodeoxygenation process [9]. It has been reported in a limited number of micro-scale studies $[10,11]$ that high aromatic carbon (30-40 wt. \%) yields have been achieved by direct catalytic pyrolysis of lignocellulosic biomass or its constituent units of cellulose, hemicellulose and lignin in recent years [12].

Biomass feedstocks, such as wood, agricultural and forest residues, energy plants, urban and solid industrial wastes, lumber and municipal wastes have attracted great attention as renewable energy sources in the worldwide. Turkey has high potential of agricultural renewable source with diverse crops production in 25 million hectares of arable land [13, 14]. Numerous types of plants grow in the lands of Turkey and they could be used as a source of biomass for production of clean energy or chemicals [15]. One of them, commonly named as "Persian Hogweed", is Heracleum persicum Desf. is a flowering plant in the family of Apiaceae, native to Persia or modern day Iran. The genus Heracleum with more than 120 species in the world is one of the largest genera of the Umbelliferae (Apiaceae) family. This genus is widely distributed in Asia [16] and is represented by eight species in the flora of Iran, three of which (Heracleum rechingeri, Heracleum gorganicum and Heracleum anisactis) are endemic to Iran [17]. The Persian name for the Heracleum persicum Desf. Ex Fischer is Golpar and is used as flavouring agent and spice for food in many parts of Iran. In some areas of the country, Golpar is used as a flavouring agent for making pickles. The fruits and leaves of this genus are also used as antiseptic, carminative, digestive and analgesic in the Iranian folk medicine [18-21]. However, there is no reported study of utilization of its stalks which have no value in terms of industrial or medicinal respect in the literature. Therefore, pyrolysis experiments with its stalks were carried out with $\left(\mathrm{K}_{2} \mathrm{CO}_{3}, \mathrm{ZnCl}_{2}\right)$ and without catalyts at three different temperatures $(400,500$ and $600{ }^{\circ} \mathrm{C}$ ) for the purpose of production of bio-oil or value-added chemicals.

\section{MATERIALS AND METHODS}

\subsection{Materials}

Heracleum persicum Desf. plants were collected in an agricultural zones in Aydın province of Turkey. They were harvested in June and the stems cleaned from leaves and tops and dried naturally in open air and then were ground, milled, and screen-sieved. Samples of different particle size ranging between 0.425 and $0.850 \mathrm{~mm}$ were used to in this study.

Ultimate and proximate analysis of the Heracleum persicum Desf. were performed. Ultimate analysis of the sample was carried out using an Elemental analyzer (LECO CHNS 932). The results of ultimate and proximate analyis of Heracleum persicum Desf. are given in Table 1. Chemical composition of Heracleum persicum Desf. was determined using Tappi Test methods [22]. Lignin and cellulose were determined according to Tappi T222 and Tappi T202 method respectively. Hollocellulose content was determined using the chloride method. Ash and moisture contents were determined by Tappi T211 and Tappi T264 respectively.

Table 1: Main Characteristics of the Heracleum persicum Desf

\begin{tabular}{|c|c|}
\hline \multicolumn{2}{|l|}{ Components } \\
\hline Moisture (\%) & 5.6 \\
\hline \multicolumn{2}{|l|}{ Proximate analysis ${ }^{a}(\%)$} \\
\hline Ash & 2.7 \\
\hline Lignin & 24.7 \\
\hline Cellulose & 36.3 \\
\hline Holocellulose & 67.8 \\
\hline Soxhelet extractives $\left(40-60^{\circ} \mathrm{C}\right.$ petroleum ether) & 0.7 \\
\hline \multicolumn{2}{|l|}{ Ultimate analysis ${ }^{b}(\%)$} \\
\hline Carbon & 44.16 \\
\hline Hydrogen & 5.86 \\
\hline Nitrogen & 6.45 \\
\hline Oxygen $^{c}$ & 43.53 \\
\hline $\mathrm{H} / \mathrm{C}$ molar ratio & 1.59 \\
\hline $\mathrm{O} / \mathrm{C}$ molar ratio & 0.74 \\
\hline Empirical formula & $\mathrm{CH}_{1.59} \mathrm{~N}_{0.12} \mathrm{O}_{0.74}$ \\
\hline Higher Heating Value (MJ/kg) & 15.54 \\
\hline
\end{tabular}

${ }^{a}$ Weight percentage on dry basis. ${ }^{b}$ Weight percentage on dry and ash free basis. ${ }^{\circ}$ By difference.

\subsection{Experimental Procedure}

The pyrolysis experiments were performed in a fixed-bed reactor made of stainless steel with dimensions of $70 \mathrm{~mm}$ inner diameter, $10 \mathrm{~mm}$ outer diameter and $200 \mathrm{~mm}$ height equipped with connection for inert gas input. Fixed-bed tubular reactor system is given in Figure 1. In each trial, $20 \mathrm{~g}$ of raw material was 
put inside the reactor, closed tightly with connections for inert gas entry and products output pipe connected to liquid product collecting bottles. The reactor was heated externally by an electric furnace and the temperature is controlled by a $\mathrm{NiCr}-\mathrm{Ni}$ thermocouple placed inside the bed. The liquid collecting bottles were cooled to $-10{ }^{\circ} \mathrm{C}$ using frozen salt-ethanol and water mixture and the temperature kept constant as $-10{ }^{\circ} \mathrm{C}$ until no more gas is evolved from pyrolysis process. The gas product was discharged into a chimney through a hose and a fan. During the whole pyrolysis process, nitrogen gas is circulated in the reactor with $100 \mathrm{~cm}^{3} /$ min constant flowing rate to provide the inert atmosphere inside the reactor. By inputing the desired variables to the control unit in heater, pyrolysis experiments at different conditions have been performed.

The pyrolysis experiments were done in two series. In the first one, experiments without catalyst at three different temperatures $\left(400,500\right.$ and $\left.600{ }^{\circ} \mathrm{C}\right)$ with a constant heating rate $50{ }^{\circ} \mathrm{C} / \mathrm{min}$. were carried out to investigate the effect of temperature. The condensed liquid products which contain an aqeous and oil phase were collected in bottles. They were washed with dichloromethane, put in a separating funnel and separated from each other by decantation. Bio-oil is dried with anhydrous sodium sulphate and recovered by evaporating the solvent in a rotary evaporator at temperature of $313 \mathrm{~K}$ and reduced pressure of $11 \mathrm{kPa}$ and its yield was calculated. After cooling the pyrolysis reactor, the amount of bio-char left behind was removed and weighed. The amount of gas evolved was calculated by subtraction of amount of bio-char and liquid product from 20 , the amount initial raw material. In the second group of experiments, two different catalysts $\left(\mathrm{K}_{2} \mathrm{CO}_{3}, \mathrm{ZnCl}_{2}\right)$ with $10 \%$ by weight were added to reactor and pyrolysis experiments at the same temperatures used in non-catalytic runs with a constant heating rate of $50{ }^{\circ} \mathrm{C} / \mathrm{min}$. were carried out to investigate the effect of catalyst on product yields. Upon completion of all experiments, the product yields were calculated and expressed on dry and ash free basis.

\section{RESULTS AND DISCUSSION}

\subsection{Effect of Temperature and Catalyst on Product Yields}

The conversion $^{a}$ and distribution of products obtained by pyrolysis of at different temperatures with and without catalyst in Table 2. The effects of temperature and catalysts on conversion and product yields are given in Figures 2-5. The data given in the Figures 2-5. were obtained from the experimental runs (Table 2) at different temperatures ranging from $400{ }^{\circ} \mathrm{C}$ to $600{ }^{\circ} \mathrm{C}$ with heating rate of $50{ }^{\circ} \mathrm{C} / \mathrm{min}$. Figures 2 and 5 indicate that temperature has a positive effect on both conversion and gas yields at all temperatures. As for the bio-oil yields, temperature has increased the yields when temperature was increased from $400{ }^{\circ} \mathrm{C}$ until $500{ }^{\circ} \mathrm{C}$, but then decreased slightly at $600{ }^{\circ} \mathrm{C}$. As it is seen from Table 2, when temperature is increased from 400 to $500{ }^{\circ} \mathrm{C}$, liquid product yield was increased

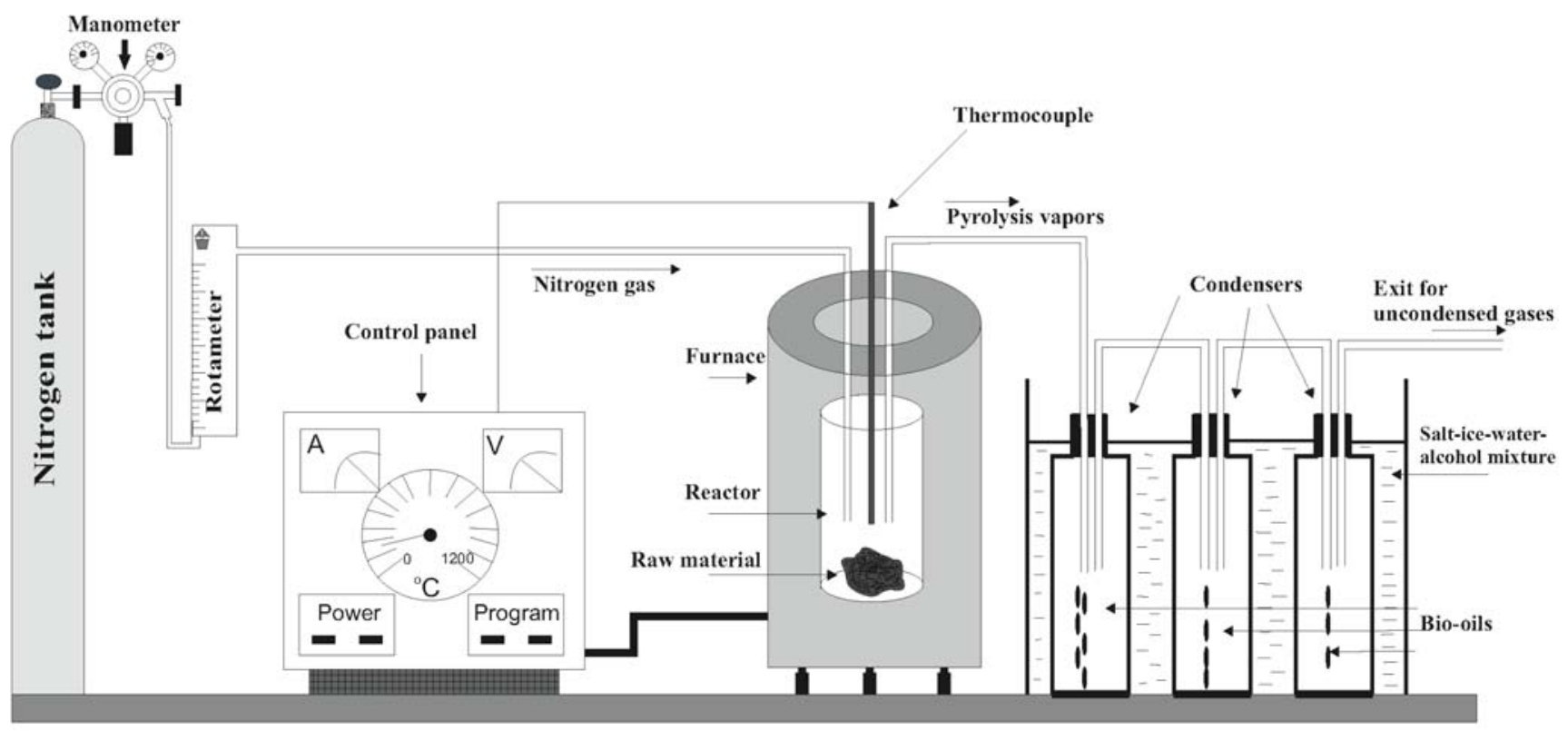

Figure 1: Fixed-bed tubular reactor system. 
Table 2: The Conversion ${ }^{a}$ and Distribution of Products Obtained by Pyrolysis of Heracleum persicum Desf. at Different Temperatures

\begin{tabular}{|c|c|c|c|c|}
\hline Temperature $\left({ }^{\circ} \mathrm{C}\right)$ & Conversion (\%) & Bio-char (\%) & Bio-oil (\%) & Gas (\%) \\
\hline \multicolumn{5}{|l|}{ No catalyst } \\
\hline $500{ }^{\circ} \mathrm{C}$ & 70.62 & 29.38 & 37.26 & 33.36 \\
\hline $600^{\circ} \mathrm{C}$ & 73.46 & 26.54 & 35.72 & 37.74 \\
\hline $400^{\circ} \mathrm{C}$ & 69.53 & 30.47 & 36.91 & 32.62 \\
\hline $500^{\circ} \mathrm{C}$ & 77.13 & 22.87 & 41.42 & 35.71 \\
\hline $600^{\circ} \mathrm{C}$ & 79.21 & 20.79 & 39.28 & 39.93 \\
\hline \multicolumn{5}{|l|}{ Zinc chloride (10\%) } \\
\hline
\end{tabular}

${ }^{a}$ Mass fraction percentage of the dry and ash free feedstock.

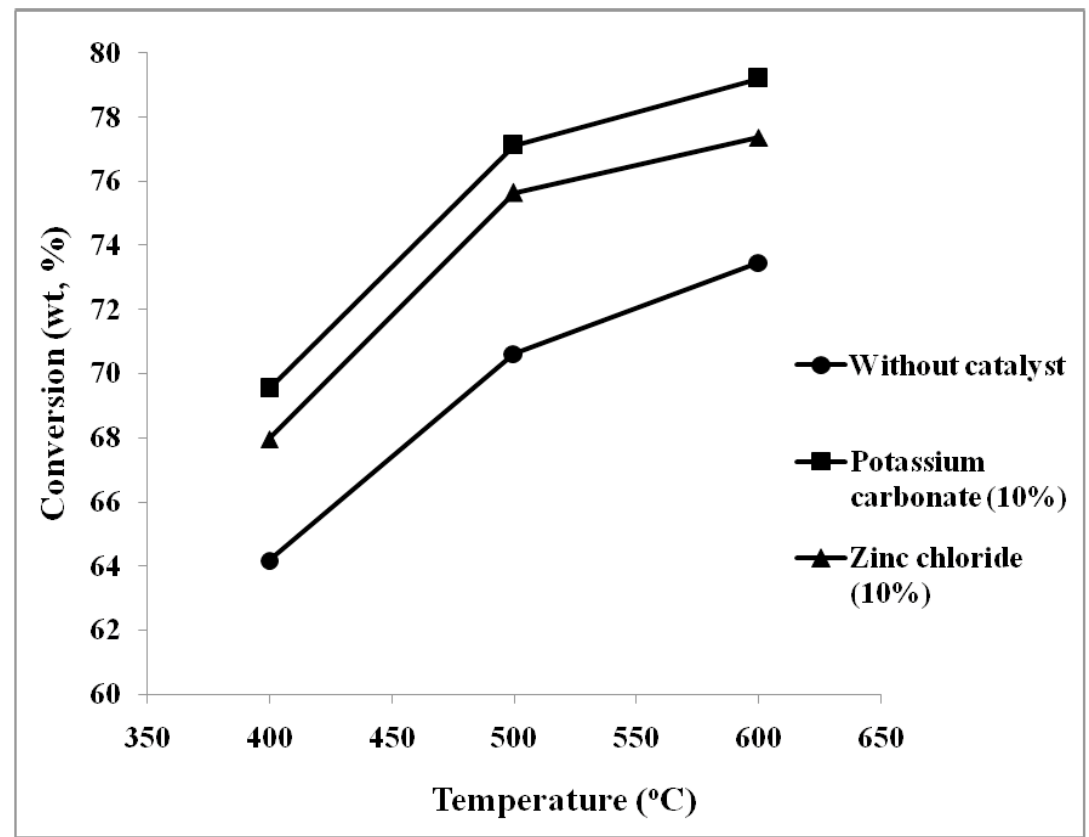

Figure 2: Effect of temperature and catalyst on conversion.

from $33.41 \%$ to $37.26 \%$, but decreased to $35.72 \%$ at $600{ }^{\circ} \mathrm{C}$ in the non-catalytic runs.

According to literature, temperature is considered as the most important parameter on product yields in pyrolysis of biomass [23-25]. The amount of gasesous products were increased constantly with increasing pyrolysis temperature. When temperature was increased from 400 to $600{ }^{\circ} \mathrm{C}$, the gaseous product yields were increased from $30.76 \%$ to $37.74 \%$ in the non-catalytic runs. The reason for decreasing of liquid product yields and increasing of gaseous product yields at higher temperatures is due to be the formation of secondary cracking reactions of the pyrolysis vapors. Besides, secondary decomposition of the biochars may produce non-condensable gaseous substances at higher temperatures which condributes an increase in gaseous products [26, 27]. Bio-char yields have decreased constantly with increasing the pyrolysis temperature. This is because of greater primary 


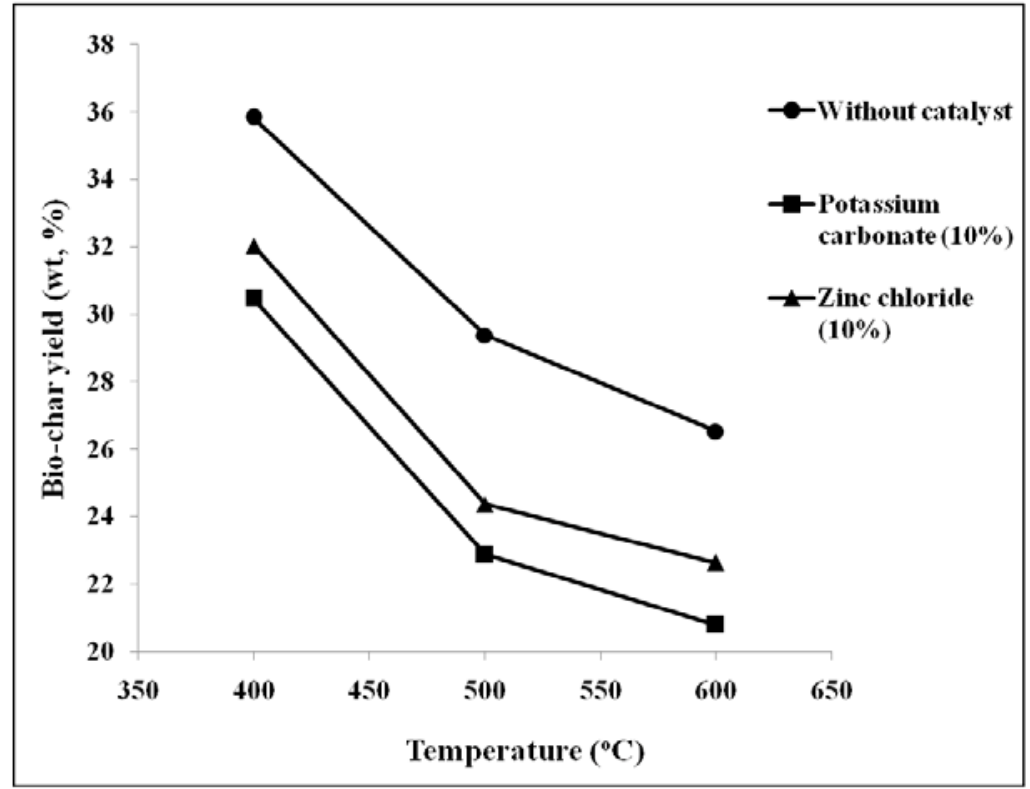

Figure 3: Effect of temperature and catalyst on bio-char yields.

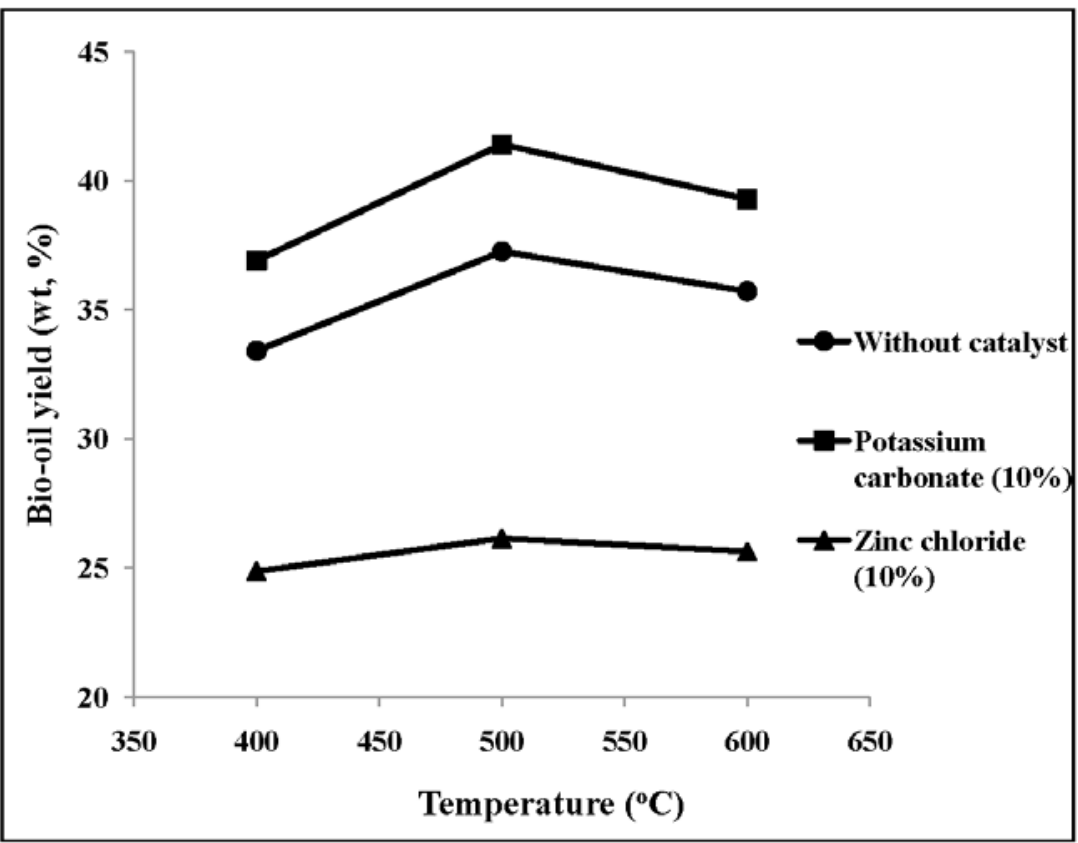

Figure 4: Effect of temperature and catalyst on bio-oil yields.

decomposition of the biomass or secondary decomposition of the char residue, leading the higher conversions with increasing temperature. As pyrolysis temperature increases from 400 to $600{ }^{\circ} \mathrm{C}$, bio-char yields were decreased from $35.83 \%$ to $26.54 \%$ in the non-catalytic runs.

Pyrolysis experiments with catalysts were also carried out at a constant heating rate of $50{ }^{\circ} \mathrm{C} / \mathrm{min}$. at the same temperatures used in non-catalytic runs to determine the effect of catalysts $\left(\mathrm{ZnCl}_{2}\right.$ and $\left.\mathrm{K}_{2} \mathrm{CO}_{3}\right)$ on the product yields. As seen from Figures 2-5, catalysts effected the product yields differently. Both catalysts have increased the conversion with increasing temperature with non-catalytic runs. Potassium carbonate, on the other hand, was more effective than zinc chloride in terms of conversion. The highest conversion of $79.21 \%$ was achived with potassium carbonate in the catalytic runs at $600{ }^{\circ} \mathrm{C}$. On the other hand, effects of catalysts on liquid product yields were very different from each other. In the experiments performed with zinc chloride, the liquid product yields 


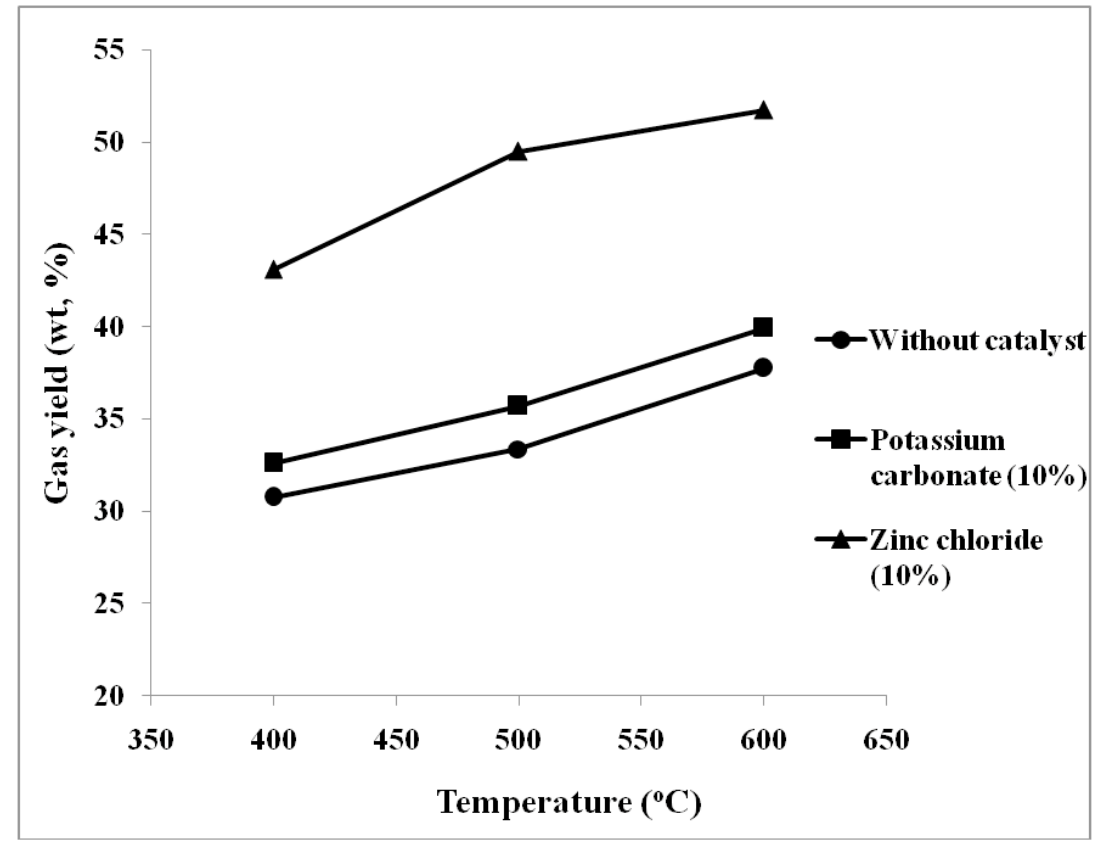

Figure 5: Effect of temperature and catalyst on gas yields.

were lower than in the non-catalytic runs at all temperatures. The liquid products yields were $24.86 \%$, $26.14 \%$ and $25.63 \%$ at 400, 500 and $600{ }^{\circ} \mathrm{C}$ respectively. On the other hand, potassium carbonate, which had more positive effect on conversion than zinc chloride, the liquid product yields were higher than the ones obtained in the non-catalytic runs at all temperatures. The liquid product yield, which was $37.26 \%$ without catalyst, reached the maximum value of $41.42 \%$ with potassium carbonate at $500{ }^{\circ} \mathrm{C}$. Both catalysts have increased thegaseous product yields in comparison with non-catalytic runs. For example, the gas product yield of $37.74 \%$ at $600{ }^{\circ} \mathrm{C}$ without catalyst has increased to $39.93 \%$ and $51.74 \%$ with $10 \%$ potassium carbonate and zinc chloride at the same temperature respectively.

In recent years, many studies have been conducted investigating the effect of catalysts on product yields of biomass samples. The using of a catalyst could make significant changes on the properties and yields of pyrolysis products. Using a catalyst had different effects on the liquid yields, which has increased the yields in some studies while in others, it had negative effect and decreased the liquid yields Similar results were obtained for bio-char and gaseous product yields which were either increased or decreased with catalysts. Nishimura et al. [28] has performed the cellulose pyrolysis with potassium carbonate $\left(\mathrm{K}_{2} \mathrm{CO}_{3}\right)$ under relatively high heating rate to elucidate the role of alkali metals on wood pyrolysis. With the addition of potassium carbonate, an increase in gaseous yield and a decrease in tar yield and a significant decrease in the initiation temperature of pyrolysis were observed.

The liquid product obtained in pyrolysis contains an aqueous phase and bio-oil or oil phase which is generally named as pyrolytic liquid. It is a black liquid containing highly oxygenated compounds used as boiler fuel in power stations for heat production. If it is intended to be used as transportation fuels, they should be upgraded first by hydrodeoxygenation to produce aromatics or hydrocarbons, or catalytic cracking by using zeolite to produce aromatic light alkanes.

\subsection{Characterization of Bio-Chars by Elemental and FT-IR Analysis}

Some of the bio-chars obtained at optimum conditions $\left(500{ }^{\circ} \mathrm{C}\right)$ were analyzed and characterized by elemental and FT-IR analysis. Elemental analyses were performed with LECO CHNS 932 Elemental Analyser and infrared analysis with a Perkin Elmer Spectrophotometer. The results of elemental analyses of four bio-chars are given in Table 3 . Tables 3 shows that bio-chars have higher carbon and lower oxygen contents than the original raw material and accordingly have higher heating values than the raw material. As seen Table 3 , the higher heating values of bio-chars are higher than $20 \mathrm{MJ} / \mathrm{kg}$, in comparison with the low higher heating value $(15.54 \mathrm{MJ} / \mathrm{kg})$ of the raw material.

The FT-IR spectrums of the bio-chars obtained at $500{ }^{\circ} \mathrm{C}$ are given in Figure 6. When they are compared 
Table 3: Elemental Analyses of Bio-Chars Obtained at $500{ }^{\circ} \mathrm{C}$

\begin{tabular}{|c|c|c|c|}
\hline Components & Without catalyst & With $\mathbf{Z n C l}_{\mathbf{2}}$ (10\%) & With $\mathrm{K}_{\mathbf{2}} \mathrm{CO}_{\mathbf{3}}$ (10\%) \\
\hline \hline Carbon & 62.781 & 63.827 & 66.821 \\
\hline Hydrogen & 3.024 & 3.192 & 0.531 \\
\hline Nitrogen & 0.754 & 0.824 & 28.664 \\
\hline Oxygen $^{\text {a }}$ & 33.441 & 32.157 & 0.634 \\
\hline H/C molar ratio & 0.578 & 0.600 & 0.321 \\
\hline O/C molar ratio & 0.399 & 0.377 & 22.53 \\
\hline
\end{tabular}

${ }^{\mathrm{a} B y}$ difference.

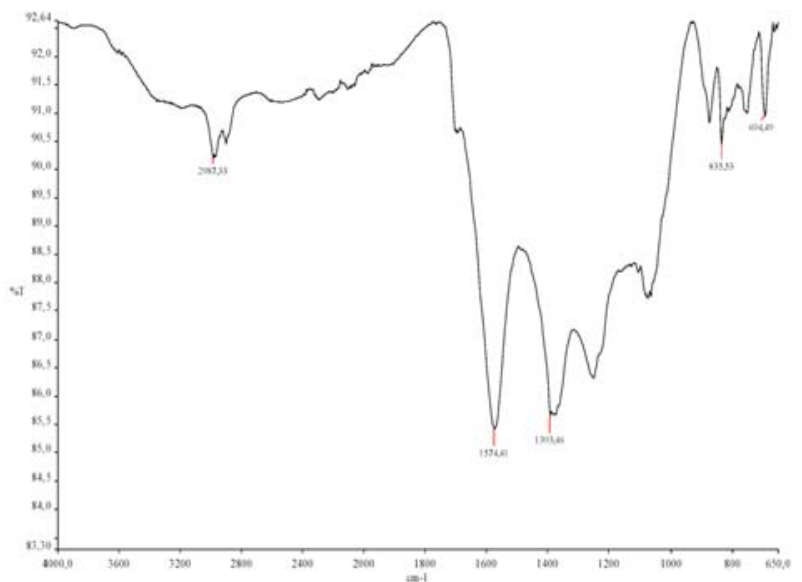

a) Without catalyst

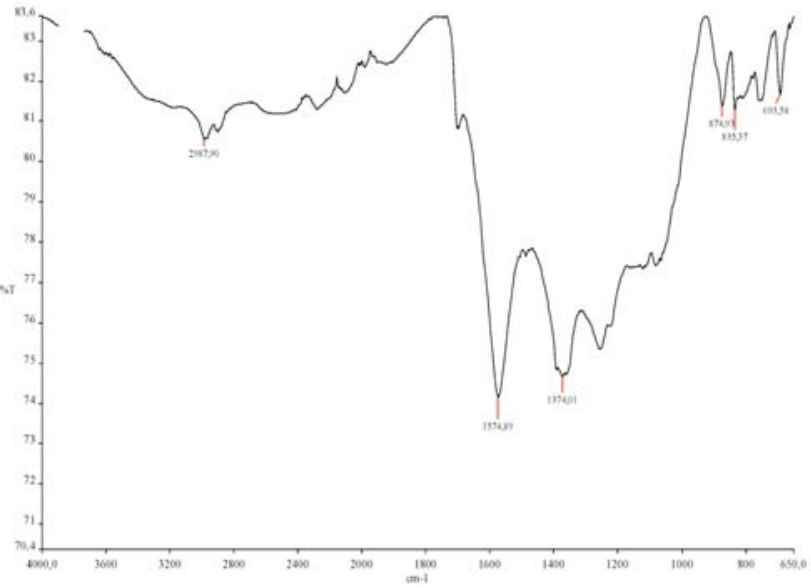

b) With $10 \% \mathrm{~K}_{2} \mathrm{CO}_{3}$

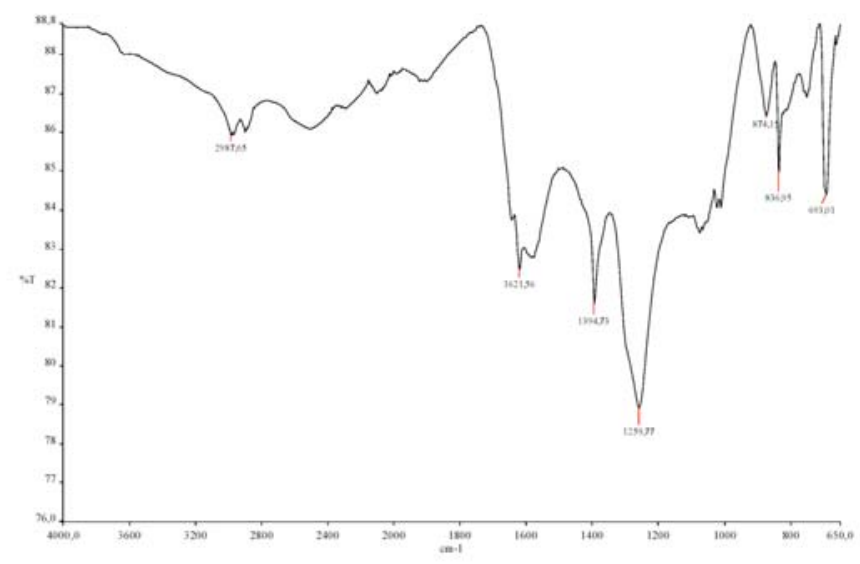

c) With $10 \% \mathrm{ZnCl}_{2}$

Figure 6: FT-IR spectrums of bio-chars obtained at $500{ }^{\circ} \mathrm{C}$.

with raw material, there have been significant changes in the FT-IR spectrum as a result of pyrolysis. The $\mathrm{O}-\mathrm{H}$ stretching vibration band at $3335 \mathrm{~cm}^{-1}$ has been dissappeared for all bio-chars which shows that the oxygen was removed from raw material during pyrolysis which causes the phenolic and aromatic structures to crack producing carbonaceous solid products. The FT-IR spectrums of bio-chars are very similar to each others. The observed two weak intense bands at $2987 \mathrm{~cm}^{-1}$ are assigned to aliphatic $\mathrm{C}-\mathrm{H}$ stretching. The $\mathrm{C}-\mathrm{C}$ stretching vibrations between 1350 and $1650 \mathrm{~cm}^{-1}$ indicate the presence of aromatics and alkanes. The $\mathrm{C}-\mathrm{O}$ stretching absorbance peaks observed between 1050 and $1350 \mathrm{~cm}^{-1}$ indicate the 


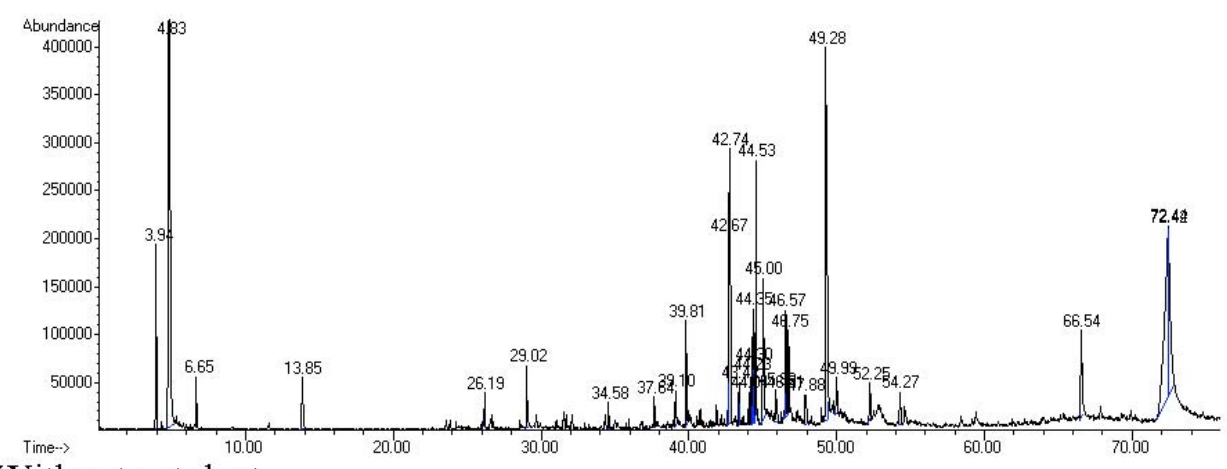

a) Without catalyst

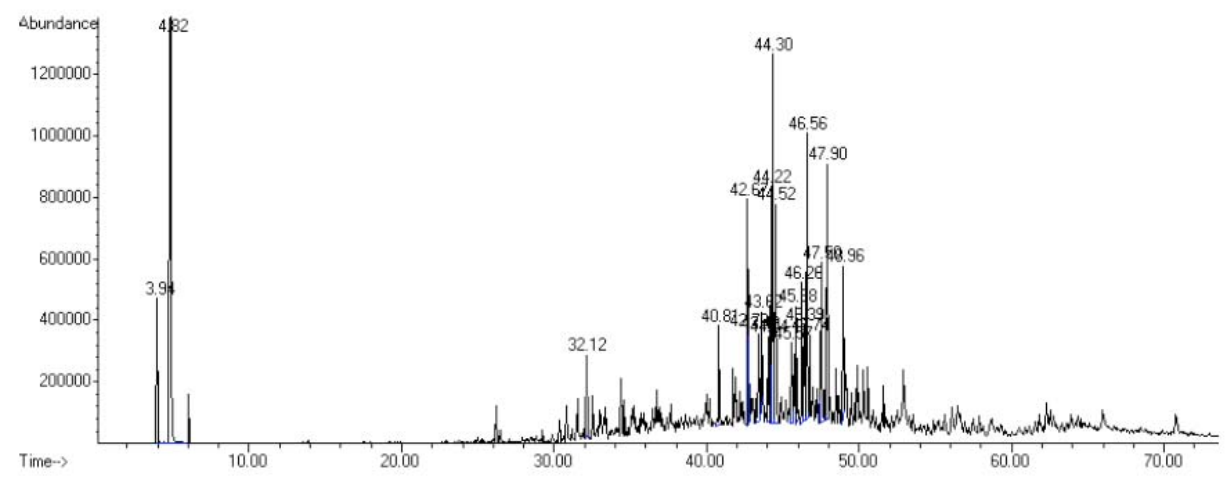

b) With $10 \% \mathrm{ZnCl}_{2}$

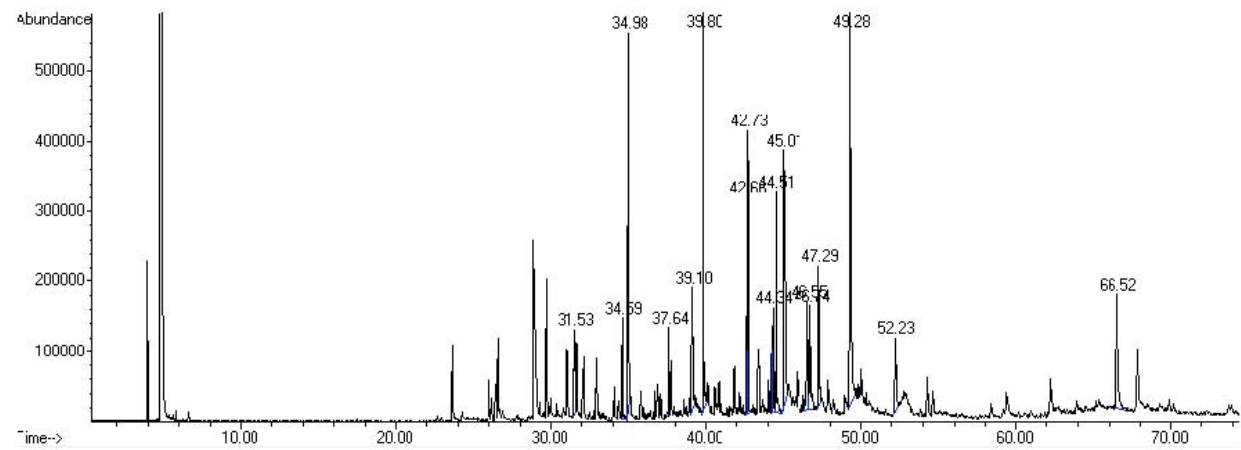

c) With $10 \% \mathrm{~K}_{2} \mathrm{CO}_{3}$

Figure 7: GC-MS spectrums of bio-oils obtained at $500{ }^{\circ} \mathrm{C}$.

presence of primary, secondary and tertiary alcohols, phenols, ethers and esters. Besides, $\mathrm{C}-\mathrm{H}$ out-of-plane bending vibrations observed between 700 and 900 $\mathrm{cm}^{-1}$ shows the presence aromatic compounds. From FT-IR analyses, it can be conclude that bio-chars obtained by pyrolysis are mainly composed of aromatic and aliphatic compounds.

\subsection{Characterization of Bio-Oils by GC-MS Analysis}

The bio-oils obtained at optimum conditions (500 ${ }^{\circ} \mathrm{C}$ ) were analyzed and characterized by GC-MS. The GC-MS analyses were performed at scientific and technological research center in Malatya Inonu
University on Agilent GC-MS 7890A/5975C series. The column (HP -INNOWAX, length: $60 \mathrm{~m}$., I.D.: 0,250 mm, film: $0,25 \mu \mathrm{m}$ and temperature limits: from $40^{\circ} \mathrm{C}$ to $260^{\circ} \mathrm{C}$ ) and injector temperatures were the same as those for GC. Chemical constituents were identified by comparison of their retention indices with literature values [29] and their mass spectral data with those from the Wiley7n.1, ADAMS.1 and NIST05a.L mass spectral databases.

The GC-MS spectrums of the bio-oils obtained at $500{ }^{\circ} \mathrm{C}$ are given in Figure 7. The list of the compounds identified by GC-MS is given in Table 4 . There are different types of compounds with different molecular 
Table 4: Main Chemical Compounds Present in the Bio-Oils Obtained at $500{ }^{\circ} \mathrm{C}$

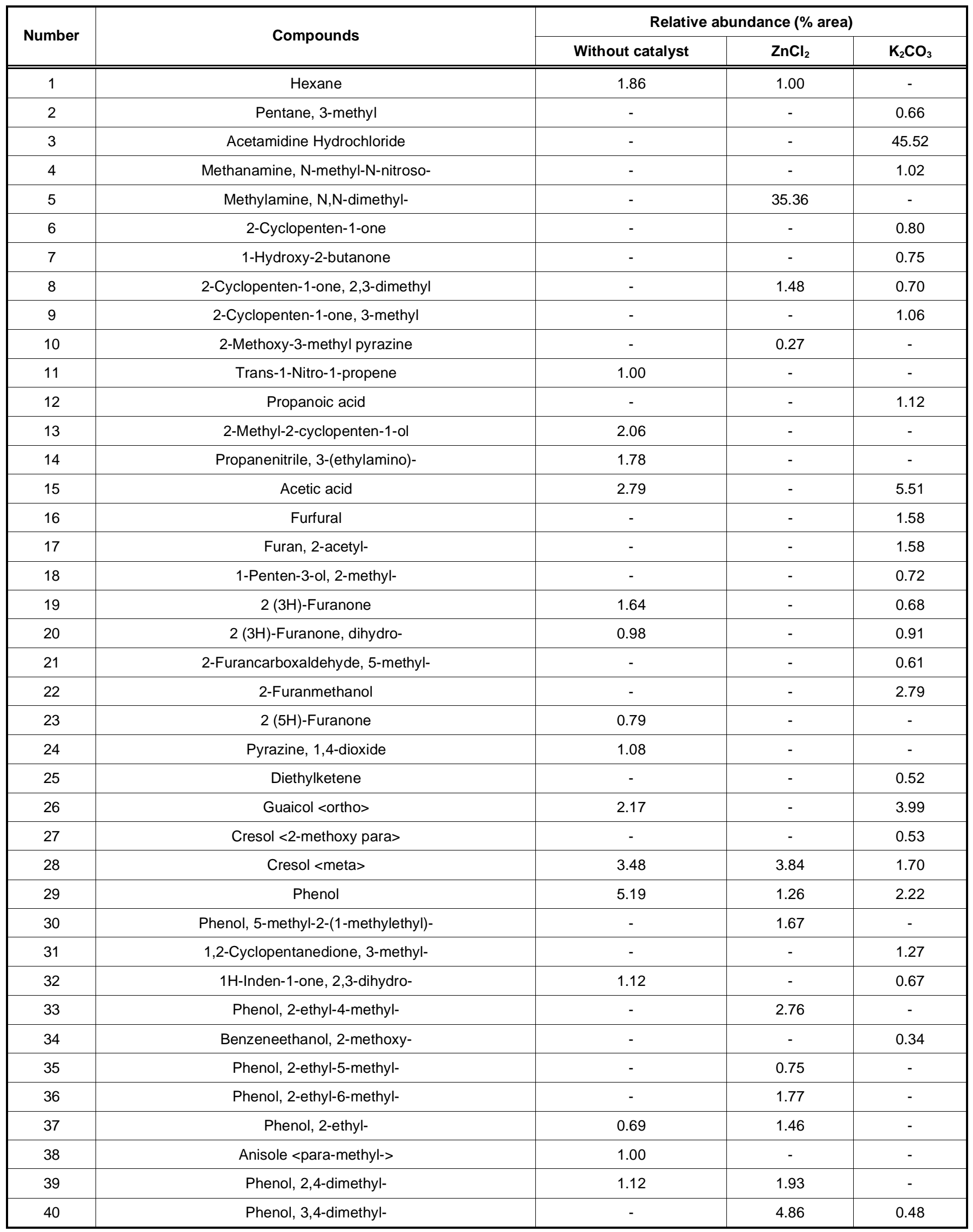


(Table 4). Continued.

\begin{tabular}{|c|c|c|c|c|}
\hline \multirow{2}{*}{ Number } & \multirow{2}{*}{ Compounds } & \multicolumn{3}{|c|}{ Relative abundance ( $\%$ area) } \\
\hline & & Without catalyst & $\mathrm{ZnCl}_{2}$ & $\mathrm{~K}_{2} \mathrm{CO}_{3}$ \\
\hline 41 & Phenol, 2,5-dimethyl- & - & 2.81 & 0.44 \\
\hline 42 & Cresol<para $>$ & 2.57 & 4.00 & 2.54 \\
\hline 43 & Phenol, 3-ethyl- & 1.98 & 1.36 & 0.95 \\
\hline 44 & Phenol, 3-ethyl-5-methyl- & - & 2.82 & - \\
\hline 45 & Phenol, 2-ethyl- & 3.82 & - & 1.55 \\
\hline 46 & Phenol, 3,4-diethyl- & - & 1.01 & - \\
\hline 47 & Phenol, 2,6-dimethoxy- & 11.85 & - & 6.97 \\
\hline 48 & 1,2,3-Trimethoxybenzene & - & 0.72 & - \\
\hline 49 & 1,4-Benzodioxin, 2,3-dihydro- & 4.07 & - & - \\
\hline 50 & Benzene, 1-ethyl-4-methoxy- & - & 3.31 & - \\
\hline 51 & Phenol, 2,6-dimethyl- & 0.97 & 1.80 & - \\
\hline 52 & Phenol, 2,3-dimethyl- & 1.17 & 6.80 & - \\
\hline 53 & Phenol, 2,4,6-trimethyl- & - & 1.03 & - \\
\hline 54 & 2-Methoxy-4-vinylphenol & - & - & 1.27 \\
\hline 55 & Phenol, 2-methoxy-4-(2-propenyl)- & - & - & 1.35 \\
\hline 56 & 1,4:3,6-Dianhydro-.alpha.-glucopyranose & - & - & 0.68 \\
\hline 57 & Phenol, 2,4,5-trimethyl- & - & 5.53 & - \\
\hline 58 & Phenol, 2,3,5-trimethyl- & - & 5.86 & - \\
\hline 59 & Phenol, 3,4,5-trimethyl- & - & 1.15 & - \\
\hline 60 & 3-Pentanone, 2,2-dimethyl- & 4.46 & - & 3.41 \\
\hline 61 & Phenol, 2-(1,1-dimethylethyl)- & - & 1.43 & - \\
\hline 62 & 2-Hepten-4-ol & 1.51 & - & - \\
\hline 63 & Benzeneamine, 2-methoxy-5-nitro- & 1.39 & - & - \\
\hline 64 & 2-acetyl-3-methy-imidazo [2,1-b] thiazol & - & - & 0.77 \\
\hline 65 & 2-Pentenoic acid, 2-methyl- & 1.37 & - & - \\
\hline 66 & 1,2-Benzenedicarboxylic acid, diisooctyl ester & 22.01 & - & - \\
\hline 67 & trans-Benzene dioxide & - & - & 2.25 \\
\hline 68 & Phthalic anhydride & 12.61 & - & - \\
\hline 69 & Cinnamic acid, 3-hydroxy-4-methoxy- & - & - & 1.13 \\
\hline 70 & Methanamine, N,N-dimethyl- & 1.48 & - & - \\
\hline 71 & 5-isopropyl-2-methyl phenol & - & 1.15 & - \\
\hline
\end{tabular}

structures and molecular weights in the bio-oils produced by the thermal degradation of hemicellulose, cellulose and lignin found in the raw material.

The compounds identified by GC-MS are consist of complex mixtures of organic compounds including furans, ketones, alcohols, carboxylic acids, benzene derivatives, alkenes, amines and amides. Furans and its derivatives are obviously formed from decompositon of cellulose while acetic acid is formed from the decomposition of hemicelluloses. Many of the compounds identified in bio-oils are phenolics and its derivatives which are formed by degredation of lignin in the raw material. They consist of phenols, methoxy phenols and alkyl phenols. The most abundant compounds produced from decomposition of lignin in the bio-oils are 2,6-dimethoxy-phenol, cresol and guaicol. As bio-oils obtained by pyrolysis can be used not only as a fuel in engines or boilers, but also as a valuable organic chemicals, phenols could be considered as one of them for its commercial value.

\section{CONCLUSION}

In this study, pyrolysis of Heracleum persicum Desf. was carried out to obtain solid (bio-char) and liquid (bio-oil) products at three different temperatures 
ranging from 400 to $600{ }^{\circ} \mathrm{C}$ with and without catalyst. It was found that the optimum condition for bio-oil formation is at $500{ }^{\circ} \mathrm{C}$ both in catalytic and noncatalytic runs. The effects of different catalysts on degradation of Heracleum persicum Desf. were also investigated and potassium carbonate was found to be more effective than zinc chloride in terms of bio-oil formation. The compositions of the bio-chars and biooils were characterized by elemental, FT-IR and GCMS analysis. From the results, it is concluded that Heracleum persicum Desf. could be used to produce bio-chars and bio-oils with higher heating values or valuable chemicals by pyrolysis process.

\section{REFERENCES}

[1] Garg HP, Datta G. Global Status on Renewable Energy. Solar Energy Heating and Cooling Methods in Buildings, International Workshop, Iran University of Science and Technology 1998; 19-20.

[2] Demirbaş A, Arin G. An Overview of Biomass Pyrolysis. Energ Source 2002; 24: 471-82. http://dx.doi.org/10.1080/00908310252889979

[3] Hall DO, Hemstock SL, House J. Rosillo-CaUe F. Biomass energy and the global carbon balance. In Renewable Energy and the Environment (edited by A. A. M. Sayigh). New York: Pergamon Press 1992.

[4] Demirbaş A. Biorefinery Technologies for Biomass Upgrading, Energ Source Part A 2010; 32: 1547-58. http://dx.doi.org/10.1080/15567030902780394

[5] Demirbaş A. Products from Lignocellulosic Materials via Degradation Processes. Energ Source Part A 2008; 30(1): 27-37.

http://dx.doi.org/10.1080/00908310600626705

[6] Özçimen D. Ersoy-Meriçboyu A. A study on the carbonization of grapeseed and chestnut shell. Fuel Process Technol 2008; 89: 1041-46.

http://dx.doi.org/10.1016/j.fuproc.2008.04.006

[7] Mckendry P. Energy production from biomass (part 1): Overview of biomass. Bioresource Technol 2002; 83: 37-46. http://dx.doi.org/10.1016/S0960-8524(01)00118-3

[8] Nisar J, Ali M, Awan IA. Catalytic Thermal Decomposition of Polyethylene by Pyrolysis Gas Chromatography. Chil Chem Soc 2011; 56(2): 653-55.

http://dx.doi.org/10.4067/S0717-97072011000200006

[9] Williams PT, Nugranad N. Comparison of products from the pyrolysis and catalytic pyrolysis of rice husks. Energy 2000; 25: 493-13.

http://dx.doi.org/10.1016/S0360-5442(00)00009-8

[10] French R, Czernik S. Catalytic pyrolysis of biomass for biofuels production. Fuel Process Technol 2010; 91: 25-32. http://dx.doi.org/10.1016/j.fuproc.2009.08.011

[11] Carlson TR, Tompsett GA, Conner WC, Huber GW. Aromatic production from catalytic fast pyrolysis of biomass-derived feedstocks. Top Catal 2009; 52: 241-52. http://dx.doi.org/10.1007/s11244-008-9160-6

[12] Thangalazhy-Gopakumar S, Adhikari S, Chattanathan SA. Gupta RB. Catalytic pyrolysis of green algae for hydrocarbon production using $\mathrm{H}+\mathrm{ZSM}-5$ catalyst. Bioresource Technol 2012; 118: 150-57.

http://dx.doi.org/10.1016/j.biortech.2012.05.080

[13] Aysu T, Turhan M, Küçük MM. Liquefaction of Typha latifolia by supercritical fluid extraction. Bioresource Technol 2012; 107: 464-70.

http://dx.doi.org/10.1016/j.biortech.2011.12.069

[14] Aysu T, Küçük MM. Liquefaction of Giant Reed (Arundo donax L.) by Supercritical Fluid Extraction. Fuel 2013; 103: 758-63.

http://dx.doi.org/10.1016/j.fuel.2012.07.001

[15] Aysu T. Supercritical fluid extraction of reed canary grass (Phalaris arundinacea). Biomass Bioenerg 2012; 41: 139-44. http://dx.doi.org/10.1016/j.biombioe.2012.02.024

[16] Pimenov MG, Leonov MV. The Asian Umbelliferae biodiversity database (ASIUM) with particular reference to South-West Asian Taxa. Turk J Bot 2004: 28: 139-45.

[17] Rechinger $\mathrm{KH}$. Apiaceae. In Flora Iranica. Graz: Akademische Druck-u.Verlagsanstalt 1982.

[18] Amin G. Popular medicinal plants of Iran. Tehran: Tehran University of Medical Sciences Press 2008.

[19] Naraghi M. Medicinal flowers and plants. Tehran: Amir Kabir Publications 1972.

[20] Zargari A. Medicinal plants (Vol. 2). Tehran: Tehran University Publications 1988.

[21] Firuzi O, Asadollahi M, Gholami M, Javidnia K. Composition and biological activities of essential oils from four Heracleum species. Food Chem 2010; 122: 117-22. http://dx.doi.org/10.1016/j.foodchem.2010.02.026

[22] Tappi Test Methods. Tappi Press, Atlanta, Georgia 1998.

[23] Luo Z, Wang S, Liao Y, Zhou J, Gu Y, Cen K. Research on biomass fast pyrolysis for liquid fuel. Biomass Bioenerg 2004; 26: 455-62.

http://dx.doi.org/10.1016/j.biombioe.2003.04.001

[24] Ertaş M, Alma MH. Pyrolysis of laurel (Laurus nobilis L.) extraction residues in a fixed-bed reactor: Characterization of bio-oil and bio-char. J Anal Appl Pyrol 2010; 88: 22-29. http://dx.doi.org/10.1016/j.jaap.2010.02.006

[25] Onay Ö. Influence of pyrolysis temperature and heating rate on the production of bio-oil and char from safflower seed by pyrolysis, using a well-swept fixed-bed reactor. Fuel Process Technol 2007; 88: 523-31.

http://dx.doi.org/10.1016/j.fuproc.2007.01.001

[26] Demiral i, Şensöz S. Fixed-Bed Pyrolysis of Hazelnut (Corylus Avellana L.) Bagasse: Influence of Pyrolysis Parameters on Product Yields. Energ Source Part A 2006; 28(12): 1149-58.

http://dx.doi.org/10.1080/009083190966126

[27] Keleş S, Kaygusuz K, Akgün M. Pyrolysis of Woody Biomass for Sustainable Bio-oil. Energ Source Part A 2011; 33(9): 879-89. http://dx.doi.org/10.1080/15567030903330652

[28] Nishimura M, Iwasaki S, Horio M. The role of potassium carbonate on cellulose pyrolysis. J Taiwan Inst Chem E 2009; 40 (6): 630-37.

http://dx.doi.org/10.1016/j.jtice.2009.05.005

[29] Adams RP. Identification of Essential Oil Components by Gas Chromatograph/ Quadrupole Mass Spectroscopy. 4th ed. Carol Stream IL: Allured Publishing Corporation 2007. 